\title{
A Critical Review of Immigrant Children's Literacies and Identities from a Deleuzian Perspective
}

\author{
Yan Zhang \\ yanzhang@ucalgary.ca
}

\begin{abstract}
This article examines how Deleuze and Guattari's rhizome concept can be applied to educational research about immigrant children's literacies and identities. It explores the intersection of literacy and identity encountered in sociocultural and poststructural (particularly a Deleuzian perspective) paradigms, reviews studies on immigrant children's literacy and identity from these two perspectives, and discusses challenges posed by each. The rhizome concept advances a new way of research about immigrant children, who are often marginalized by the dominant school culture. This new way of research emphasizes literacy as a process of becoming, highlighting immigrant children's multilinguality, creativity, and intersections of multiple literacies across school, home and community and across global and local contexts and the fluidity of their identities. The paper finally calls for an awareness of the complications, connections and multiplicities that literacy research confronts concerning immigrant children and puts forward some pedagogical implications.
\end{abstract}

\section{Introduction}

For the last three decades, literacy has shifted from individual skills and competences of reading and writing from a cognitive perspective to a social practice from a sociocultural perspective. A social view of literacy explores how participation, interaction and relationships affect the ways in which people make sense of themselves and others (Moje \& Luke, 2009). Many studies on immigrant children ${ }^{1}$ are conducted within this sociocultural framework of literacy and identity. Such studies examine the relationships among power, discourse, and agency - particularly the positional and resourceful nature of literacy practices. For instance, some researchers find that schools and teachers overlook immigrant children's heritage languages and literacy expertise (Parke, Drury, Kenner, \& Robertson, 2002; Perry, Kay, \& Brown, 2008; Taylor, Bernhard, Garg, \& Cummins, 2008). These children are constrained and marginalized by school or classroom cultures that mirror the dominant culture in the larger host society. As a result, children may not develop adequate heritage language literacy, and may

\footnotetext{
${ }^{1}$ Immigrant children in this paper refer to both children who immigrate with their parents and those born in the host countries to parents who have immigrated.
}

Journal of Contemporary Issues in Education, 2012, 7 (1), Special Issue, pp.24-46

ISSN 1916-3460 (C) 2011 University of Alberta

http://ejournals.library.ualberta.ca/index.php/cpi/index 
face academic and emotional difficulties in school (Cummins \& Danesi, 1990). Such experiences can have a negative effect on children's identities. It is therefore recommended that teachers and schools implement pedagogical innovations and provide additive and culturally responsive literacy learning communities to affirm immigrant children's identities.

Some researchers in the field of immigrant children's literacy have viewed identity as an essential part of the self that is associated with cultural difference. From a poststructural perspective, immigrant children's identities should not be essentialized according to their culture, ethnicity, nationality, gender, religion, race, or generation. Instead, children should be free to form their own sense of identity by incorporating different aspects of varying cultures. This invites new understandings of culture and cultural belonging, and reconceptualizes difference and diversity as negotiable, strategic, and mobile (Hébert, Wilkinson, \& Ali, 2008).

Meanwhile, from a poststructural perspective, immigrant children's literate behaviors are improvisational and fluid in various domains such as school, home and community. For instance, children may engage in some classroom activities that integrate their heritage cultures and develop their literacy skills, but at other times they may dislike certain types of reading and writing. They may enthusiastically search the Internet for their favourite song lyrics, but resist obligatory grammar assignments in school. These disparities imply the transformative possibilities inherent in schools that produce new communities of practice challenging established ways of becoming literate in producing speakers, writers and artists (Masny \& Cole, 2009). Literacy, in this way, is viewed as a process of becoming - a process of being different from one's present self.

This process of becoming is elaborated in Multiple Literacies Theory (MLT). Masny and other researchers have developed MLT (Masny, 2005, 2006, 2008; Masny \& Cole, 2007, 2009), informed by Deleuze $(1990,1995)$ and Deleuze and Guattari $(1987,1994)$. MLT allows for different literacies to intersect in complex and non-linear ways across time and space. It is in the mobility of experiences that literacies are transformed and speakers, writers and artists are produced (Masny, 2009b).

The field of literacy studies is large and heterogeneous (Collins \& Blot, 2003). The concept of literacy has, as discussed, been theorized from a sociocultural perspective as a social practice, and from a poststructural perspective as a process of becoming. Both views have influenced and been influenced by conceptual developments in theories of identity. A delineation of these conceptual developments including reviews of representative studies will illuminate the fluidity and multiplicity of immigrant children's literacy and identity. 


\section{Sociocultural Research of Immigrant Children's Literacies and Identities}

\section{Literacy as a Social Practice and Identity as Position}

Two models of literacy have been dominant in the field: autonomous and ideological. The autonomous model views literacy as the technical acquisition of reading and writing skills - a process that does not attend to the contexts of learners' lives (Street, 1984, 1995). The ideological model, in contrast, views literacy as a social practice. Researchers working in the New Literacy Studies (NLS) conceptualize literacy not in terms of individual cognitive skills and competencies, but as constitutive of social and cultural practices (Baker \& Luke, 1991; Barton, Hamilton, \& Ivanic, 2000; Dyson, 2001; Gee, 1996; Street, 1984, 1995). To view literacy as a social practice entails recognizing multiple literacies in everyday life, associated with different domains within which literacy is practiced, such as home, school and workplace (e.g. Barton, Hamilton, \& Ivanic, 2000; Street, 1984, 1995). It also recognizes multiple forms of literacy associated with multiple channels or modes, given the increasing variety of text forms associated with information and multimedia technologies. The New London Group (NLG) (1996) coined the term multiliteracies to argue that literacy pedagogy must account for the multimodal ways in which children engage in meaning making, such as written, visual, gestural, and tactile modes (Cope \& Kalantzis, 2000). In addition, viewing literacy as a social practice acknowledges that literacy embeds contested power relationships (Barton, Hamilton, \& Ivanic, 2000; Gee, 1996, 2008; Street, 2003). Literacies relate to power because they are "ideological" (Street, 1984), with some of them tending to dominate and marginalize others (Gee, 2008).

When aligning with an autonomous model of literacy, identity refers to a relatively stable and essentialized sense of self (Erikson, 1968). From a sociocultural perspective on literacy, identity refers to a process constructed and mediated through interaction (deFina, Schiffrin, \& Bamberg, 2006; Hébert, 2001). Researchers from this perspective emphasize the individual as an agent of his or her literacy and social practices (Moje \& Luke, 2009), and places identity at the center of literacy development (Pahl \& Rowsell, 2005).

Different conceptualizations of identity lead to different forms of literacy research, and different understandings of how literacy and identity work to develop one another (Moje \& Luke, 2009). In their comprehensive review of literacy and identity studies, Moje and Luke (2009) describe conceptualizations of identity, positing it as (1) difference, (2) sense of self, (3) mind or consciousness, (4) narrative, and (5) position. According to the authors, these metaphors overlap in assuming identity to be socially situated, mediated, produced, fluid, and dynamic. They further propose that the identity-as-position metaphor brings together all of the other four metaphors, and is especially useful for literacy research. Similarly, Bartlett (2008) states that "contemporary literacy studies have come to rely upon the concept of identity to think about the purposeful ways in which individuals endeavor to position 
themselves through and/or in conjunction with literacy practices in social and cultural fields" (p. 37).

The metaphor of identity-as-position recognizes the flux between the assignation and assertion of identity. On the one hand, individuals might be included or excluded from membership in particular literacy practices on the basis of assignation. On the other hand, they may make claims in which they align or contrast themselves with others via literacy practices in social and cultural fields (Bartlett \& Holland, 2002; McCarthey \& Moje, 2002). In social interactions, "the subject is agentic in some spaces and not in others; literate practice plays a role in that agency, but the ways that youth are called by others in power and the ways they respond to those calls depends in part on the space and time they inhabit" (Moje \& Luke, 2009, p. 432).

In sum, a sociocultural framework focuses on the social and multimodal nature of literacy embedded in discourses of ideology, power, identity, and agency (Bartlett \&Holland, 2002; Lewis, Enciso \& Moje, 2007; Martin-Jones \& Jones, 2000; Pahl, 2002). Sociocultural Studies on Immigrant Children's Literacies and Identities

Regarding literacy through the social lens has generated a series of ethnographic studies, which capture how literacy practices and students' identities interact within school contexts (Ernst-Slavit, 1997; Michael-Luna, 2008; Soltero- González, 2008; Volk \& Angelova, 2007; Wallace, 2005). Some school policies, such as dominating cultural and language ideologies, official curriculum, and asymmetrical relationships in the classroom, can result in problematic identities in immigrant children. On the other hand, studies have also shown that certain literacy practices help children negotiate positive identities. These practices involve students in challenging and collaborative activities, allow them to experience multiple roles ranging from apprentice and expert, encourage them to contribute to the joint construction of knowledge, and validate their personal experiences and community resources (Cummins et al., 2005; Dagenais, Day, \& Toohey, 2006; Fránquiz \& De La Luz Reyes, 1998; Manyak, 2001, 2004). These and additional studies show that children have the ability to negotiate literacies, language choices, and identities in multiple contexts (Andrews \& Yee, 2006; Maguire, 2005; Pérez, 2004; Volk $\&$ Angelova, 2007). Children may move beyond school-defined modes of expression by fusing multiple sign-systems and multiple literacies as a means of expressing and exploring complex understandings of themselves and the world (Kendrick, Rogers, Smythe, \& Anderson, 2005).

Some research has documented children's out-of-school literacy and language practices (e.g. Li, 2001, 2006; Moll, Amanti, Neff, \& Gonzalez, 1992). Recognizing varied and complex literacies, these studies propose a "wealth model," which regards students' social and cultural practices as resources for literacy and language development (Pahl \& Rowsell, 2005). By legitimizing students' out-of-school literacy and language practices and validating their 
informal knowledge and lexicon, multimodal semiotic systems and sociocultural experiences, these studies have broadened what counts as literacy (Lewis \& Del Valle, 2009).

\section{Some Challenges in Sociocultural Literacy and Identity}

Engaging in ethnographic documentation of multiple literacies, the NLS have expanded literacy studies. However, there have been several concerns that the ethnographic focus of the NLS limits accounts to immediate contexts, and is therefore not attentive enough to larger social processes (Bartlett, 2007; Brandt \& Clinton, 2002; Luke, 2004; Prinsloo \& Baynham, 2008; Rampton, 1998). As Bartlett (2007, p. 64) suggests,

some [NLS] studies grant too much autonomy to local uses of literacy, [while] others hopefully (but unrealistically) herald the potential for literacy practices to interrupt enduring inequalities, and others pessimistically argue that literacy practices have little impact on social change.

Prinsloo and Baynham (2008) argue that the study of local literacy needs to look at how local literacy practices are constituted in relation to the "travelling cultures" of globalization. Similarly, Brandt and Clinton (2002) propose that literacy has the potential to transcontextualize - the ability to travel, integrate, and endure. They further argue that literacy is neither a deterministic force nor a creation of local agents. Instead, literacy participates in social practices in the form of objects and technologies. They call for the consideration of both objects and human agents as active participants in literacy practices, and argue that dichotomies between agency and social structure, local and global, and literacy and its technologies should be dissolved (Brandt \& Clinton, 2002).

Other critiques of sociocultural literacy and identity relate to "borderland Discourse," "third space," and "hybridity," - all terms coined to capture the fluidity of people who may cross multiple linguistic and cultural borders in their daily interactions. These terms imply that students should integrate knowledge and Discourses drawn from their first space (home, community and peer networks) with the second space of Discourses (work, school and church) to construct a third space or borderland Discourse (Moje et al., 2004). In relation to immigrant children, this process describes how immigrant children create a third space between the culture of their countries of origin (first space) and that of their countries of residence (second space) (Andrews \& Yee, 2006; Maguire, 2005). Lemke (2008) argues that even when individuals cross these first two spaces, the notion of hybridity or third space can reify categories as cultural ideals so long as the categories being crossed are presupposed. Similarly Kramsch (2009) now takes a critical view of the spatial metaphor of third place, which she initially conceived to capture the experience of the symbolic boundary between native speakers and non-native speakers. Kramsch surmises that third place seems too static for a relational state of mind since predicating it on the existence of a first and second place "seems too smug for a decentered subject that has to navigate several symbolic systems and their cultural and 
historical boundaries" (p. 200). Overall, these critiques and reflections imply the need for a more dynamic view of children's literacy and identity negotiation.

\section{Poststructural Research of Immigrant Children's Literacies and Identities}

\section{Poststructural Understandings of Literacies and Identities}

From a poststructural perspective, Multiple Literacies Theory (MLT) proposes a new way of conceptualizing literacy, emphasizing literacy as a process of becoming (Masny, 2009a). MLT shares certain characteristics with sociocultural approaches to literacy. First, all acknowledge that literacies are socially, culturally, historically, and politically situated, fusing with gender, race religion, culture, and power (Masny, 2008). Second, they recognize that manifestations of literacies are multimodal, i.e., visual, oral, written, and tactile (Masny, 2008). However, MLT differs from sociocultural perspectives of literacy in two ways (Masny \& Waterhouse, 2011). First, the NLS views literacy as an outcome to be achieved; whereas MLT views literacies as creative and productive processes. Second, the two approaches conceive transformation differently. Sociocultural paradigms influenced by Freire's theory of literacy (1972) regard transformation as an endpoint of individuals' emancipation from oppression. In contrast, in MLT, "there is no finality [of transformation]" (Masny, 2008, p.14) and "how transformation will actualize cannot be predicted" (Masny \& Waterhouse, 2011, p. 290). Rather, transformation is about connecting and intersecting the many aspects of life that flow through the subject and that constitute memories, desire and the mind (Masny \& Cole, 2009). Through these processes, the individual becomes different from his or her original self (Semetsky, 2006).

MLT embraces a worldview that the individual is reading, reading the world and self as texts in multiple environments (home, school, and community) (Masny, 2008). Informed by Deleuze $(1990,1995)$ and Deleuze and Guattari $(1987,1994)$, MLT sees reading as intensive and immanent. To read intensively is to read disruptively by asking how texts work and what they produce, not what they mean (Masny, 2010). To read immanently brings the thought of something. Masny and Waterhouse (2011, p. 292) use the following example to explain:

You are walking down the hallway. You smell coffee and look at the clock to see that it is four o'clock. The coming together of the walk down the hallway, the smell of coffee, and seeing the time disrupts (reading intensively) and brings on the thought of vacation, the thought of it's time to go home, the thought of ...(reading immanently).

Reading one's self happens in the process of reading the word and world, and is based on a construction of meaning that is always in movement, always in transition (Dufresne \& Masny, 2005). Reading self contributes to the shaping of one's worldview and is a way of becoming. In 
MLT, different readings in various situations become conditions of identity (Masny, 2005). It follows that MLT views identity and becoming as synonymous with literacies (Masny, 2005).

Poststructural scholars view identity as provisional and relational (Andreotti, 2008; Kramsch, 2009). The provisionality of identities can be understood in both symbolic and historical dimensions (Kramsch, 2009). First, poststructuralists suggest the self is formed through the use of language and other symbolic systems. Embedded in webs of social relations that involve multiple symbolic exchanges, individuals' subjectivities always carry potentials for change (Hébert, 2001; Kramsch, 2009). For example, students can shift their senses of themselves as language learners, painters, computer game players, text message writers, story makers and online chatters as they shift time and space in their social interactions, actual or virtual. Second, poststructuralists believe that subjects strive to see themselves and others as embodying their full range of historical possibilities - "hearing and seeing not only what they say and do, but what they could have said and done in the past, and what they could say and do in the future given the appropriate circumstances" (Kramsch, 2009, p. 18). One could say that becoming a subject means becoming aware of the gap between the words that people utter and the many meanings these words could have, as well as between who one is and who one could be. The historical possibilities and potentiality suggest the provisionality of subjectivity (Andreotti, 2008).

Identities are relational, which means an individual is formed not only through interpersonal relationships with others, but also through intrapersonal changes (Kramsch, 2009), as identity involves the conscious mind and unconscious body's memories and fantasies, identifications, and projections of the individual, all of which are always products of our socialization in a given culture (Kramsch, 2009; Weedon, 1987). In examining immigrant youth's perceptions of identifications in a society increasingly influenced by the forces of globalization, Hébert, Wilkinson and Ali (2008) have found that the immigrant youth are mobile in imagining themselves as others - as elsewhere in another place or time. They are familiar with and aware of the journeys of both their parents and themselves across cultural and other spaces of interaction. Being aware of change, they can either redefine identifications beyond and across cultural, linguistic, religious, ethnic, racial boundaries, or disregard them. These actions and experiences of imagination and awareness are relational. These relationships, in turn, can be situated within a framework consisting of continua of mobilities of mind, body, and boundaries. According to Hébert, Wilkinson and Ali (2008), mobility of mind allows for mobile identities and shifting experiences of belonging between different references of identification. Mobility of bodies refers to migration and frequent movement across places and different spaces of interaction. Mobility of boundaries recognizes shifting territorial, political, cultural, economic, social, and individual boundaries. 


\section{Literacies and Identities in a Rhizome of Deleuze and Guattari's Multiplicities}

Emphasizing the process of transformation with the folding of inside/outside and actual/virtual, literacies and identities from poststructural perspectives can be understood through Deleuze and Guattari's concept of multiplicities, one of the principles of rhizome. Deleuze and Guattari $(1987,2004)$ articulated their antihierarchical philosophical stance by contrasting the metaphors of rhizome versus the tree in attempt to derail modernist, linear thinking:

...unlike trees or their roots, the rhizome connects any point to any other point, and its traits are not necessarily linked to traits of the same nature...It is composed not of units but of dimensions, or rather directions in motion. It has neither beginning nor end, but always in a middle (milieu) from which it grows and which it overspills...(it) operates by variation, expansion, conquest, capture, offshoot...it has multiple entryways and its own lines of flight. (Deleuze \& Guattari, 2004, p. 23)

As graphically represented in Figure 1, Rhizome is a "metaphor for multidirectional growth and diverse productivity" (Semetsky, 2008, p. xiii). It describes an open system of multiple interactions and connections on various disparate planes. It is an antithesis of a root-tree structure, which has hierarchical and stratified totalities. "The rhizome, as embedded in the perplexity of the situation, goes in diverse directions instead of a single path, multiplying its own lines and establishing the plurality of unpredictable connections in the open-ended smooth space of its growth" (Semetsky, 2006, p. 73).

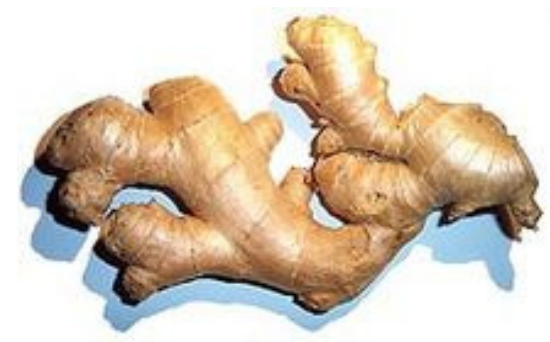

Figure 1. A representation of the rhizome.

In their book, A Thousand Plateaus: Capitalism and Schizophrenia, Deleuze and Guattari (1987) articulated central principles of rhizome theory: connection, heterogeneity, multiplicity, asignifying rupture, cartography/multiple entryways and exists (see Kamberelis, 2004 for a detailed discussion). The metaphor of rhizome stands for connection and heterogeneity. They argued that "any point of a rhizome can be connected to anything other, and must be. This is very different from the tree or the root, which plots a point, fixes an order" (Deleuze \& Guattari, 1987, p. 7). In contrast to the tree, "there are no points or positions in a rhizome, such as those found in a structure, tree, or root. There are only lines" (p. 8), producing multiplicities and making new connections. The principle of asignifying rupture states that "A rhizome may 
be broken, shattered at a given spot, but it will start up again on one of its old lines, or on new lines.... That is why one can never posit a dualism or a dichotomy, even in the rudimentary form of the good and the bad" (p. 9). Deleuze and Guattari (1987) further distinguished the tree and rhizome metaphors by contrasting notions of tracings (decalcomania) and maps (cartography). A tracing is a reproduction of the world based on existing striated structures. In contrast, "the map is open and connectable in all of its dimensions; it is detachable, reversible, susceptible to constant modification. It can be torn, reversed, adapted, to any kind of mounting, reworked by an individual, group, or social formation" (Deleuze \& Guattari, 1987, p. 12). An essential characteristic of a map is that "it always has multiple entryways" (p. 12). From this perspective, a map produces an organization of reality rather than reproducing it (Kamberelis, 2004).

Deleuze and Guattari's notion of multiplicity is highly relevant to immigrant children's literacy practices. Dufresne (2009) describes two types of Deleuze and Guattari's multiplicity. One is quantitative multiplicity, measurable in degrees and homogeneous. Another type "is qualitative, rhizoidal and heterogeneous which belongs to the virtual planes and encompasses Deleuze's theoretical concept of inside or interiority" (Dufresne, 2009, p.108). Qualitative multiplicities are "neither unities not totalities" (Deleuze, 1987, p. vii). They are "the relational entities constituted by multiple lines or dimensions irreducible to each other" (Semetsky, 2006, p. 2).

The concept of multiplicity is critical in MLT, which argues that literacies are multiple, be they personal, communal, school-based, or critical literacies. Bringing together different literacies at various times and in various contexts acknowledges plural and intersecting worldviews. It also acknowledges different and contradictory ways of meaning and experiences that flow and create a movement in reading, reading the world and self (Masny, 2005). Multiplicity, particularly qualitative multiplicity, is the essence of the subject from the Deleuzian perspective. A subject is viewed by Deleuze and Guattari from a more vitalistic perspective as a process of becoming, an ongoing process of movement and transformation (Olsson, 2009). As a qualitative multiplicity, subjectivity does not presuppose identity but is produced in a process of individuation that is already collective (Deleuze, 1987).

\section{Poststructural Studies on Immigrant Children's Literacies and Identities}

Studies of literacies and identities from Deleuzian perspectives address the theoretical and methodological challenges on the interpretation of literacy performances. Leander and Rowe (2006) argue that "literacy performances are often about creating differences, including differences in the moving, shifting relations of semiotic resources and differences in the performed identities of participants" (p. 429). Critiquing a representational mode of interpretation, they use rhizomatic analysis to map the emergence of relations and differences in literacy performances in a high school American studies classroom. During students' classroom presentations, while presenters and audience recruited different events, histories and 
objects to perform identities, many spaces were produced. This formed betweenness with "connections extending in many directions, connections forming plateaus of simultaneous becomings" (p. 449). Spatial relations, involved in literacy performances of this study, include the coming together of textual meaning and spaces, as well as the dynamic linkages and associations of subject positions. Concluding that identities are spatially performed and simultaneous becomings, Leander and Rowe propose that teachers should allow new spaces and permit new actors (e.g., bodies, images, and the built environment) in the classroom.

Rhizome is also used to map the relations and differences among multiple texts, users and activities engaged in language arts education (e.g. Hagood, 2009). Hagood first maps the multiplicity of texts which are not only multimodal but also intertextual. Since one text connects in some way to a multitude of others, the reader has to identify and interpret a network of media and discourses. Additionally, Hagood affirms the plurality of being a reader: a reader is also a writer, viewer, listener and speaker, when multiple literacies intermingle. Hagood employs the term users to describe people's relationship to these activities. Users are multifaceted because they take varying roles in the consumption, production and construction of texts. In addition, they draw different pleasures from the texts they consume, construct, and produce and in the identities made from texts. The inevitable variety of responses and roles explains why some people are proficient with some texts in particular contexts but not in others. For instance, some students might be very good at using digital software, photographs, music, and audio recordings to construct narratives of themselves as proficient literacy users, but appear less successful if required to write their stories with pens.

Hagood holds that both traditional and new forms of literacy practices should be used to help users develop a range of abilities, including "abilities to work collaboratively in spaces where intelligence is shared among users and where multitasking, navigation and negotiation of ideas to design texts are as important as decoding and summarizing texts" (p. 42). Hagood shows that language arts education, when viewed as rhizomatic, is no longer a set of cognitive skills and competencies to be learned and mastered by individuals in a sociocultural space. Instead, "language arts development must account for social skills necessary to engage with participatory literacies in multiple contexts for a variety of purposes" (p. 42).

A few studies that use the MLT framework focus on the processes that immigrant children go through as they learn different writing systems (Dufresne \& Masny, 2005; Masny, 2006, 2009b; Masny \& Cole, 2007). The studies explore some key concepts of MLT, including deterritorialization, reterritorialization, and creativity. Delueze explains deteritorializzation and reterritorialization as processes of breaking down old methods and moving into new territories (Semetsky, 2006). Foregrounding these concepts, Masny (2009b) explored a girl's understanding of writing systems as she learned Spanish, French and English simultaneously. In one vignette, the girl was making a card. She had intended to write all words in Spanish, but turned to French for words she didn't know in Spanish. The girl also added some flowers and 
other decorations on the card. With these narrative and aesthetic lines, she blurred the boundaries between writing in different languages, and between writing and drawing. Deterritorialization occurs with reterritorialization. The girl's creativity, for example can be illustrated with the word "mamagachi" which she invented to name a dessert like an Italian-style meal of pizza. Masny found that in this instance, a number of the girl's life experiences - the actual Italian words the girl had heard (e.g., mangiare meaning eat), her life with an Italian care-giver, her knowledge of how writing systems work, a meal of pizza, and her experience of making a new dessert with mom - came together in her act of creating this new word (see Figure 2). This vignette demonstrates the girl's awareness of writing systems, and the disruptive and ongoing reading in unpredictable ways. This study suggests it is important for teachers to value immigrant children's creativity drawn from their home, community, and school experiences.

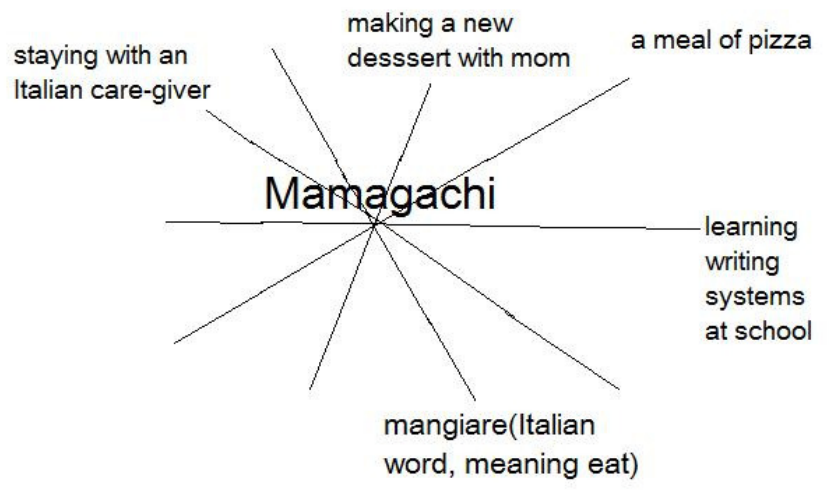

Figure 2. The invention of the word "mamagachi".

In another study, Zhang (2011) illustrates how rhizomatic multiplicities can be used to understand the process of a girl's story writing in a Mandarin-English bilingual program in Canada. The eight year old girl was composing a picture book in Mandarin (see Figures 3 and 4):
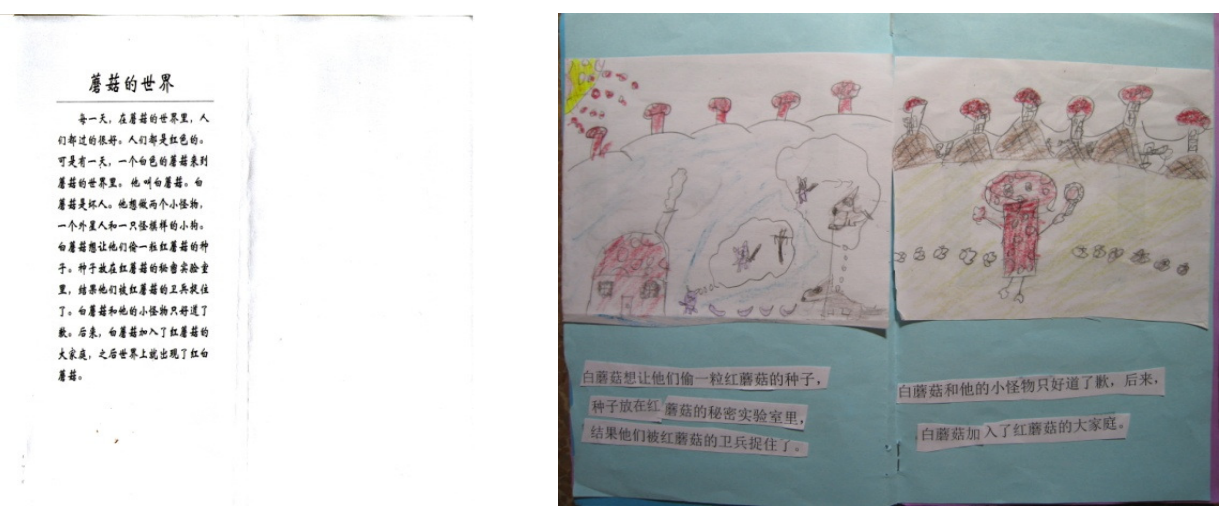

Figure 3. Typed Version.

Figure 4. One page of the story book. [Translation of the story in figure 3: The World of Mushroom 
Everybody in the world of mushroom lived a good life. Every mushroom was red. One day, a white mushroom came to the world of red mushroom. The white mushroom was evil. He asked his two monsters, an alien and a strange-looking dog, to steal a seed from a secret lab of red mushroom. But they were caught by the guards of red mushroom. They had to apologize. At the end, the white mushroom joined the world of red mushroom].

In this book, many of her life experiences, both virtual or actual, were connected and intersected. For example, when asked why she chose to write a story about the mushroom, she described how she associated the roof of a house in the shape of dotted circles in her picture (see Figure 5) with the image of a mushroom. Her participation in a workshop on healthy diets delivered by older students in her school may also have contributed to her decision to write a story about the mushroom.

Employing an MLT framework highlights various instances of boundary-blurring in the little girl's story writing. For example, she drew on Chinese characters, Pinyin and English spelling, improvising her own writing system. In Chinese, Pinyin is a phonetic alphabet using Roman letters, introduced to elementary schools as a way to teach Chinese pronunciation. Most Chinese Pinyin syllables are combinations of an initial consonant and a final sound, marked with four different tones. In students' writing, students are supposed to use Chinese characters, not Pinyin. As Figure 6 shows, in her draft writing, she wrote in Pinyin for the words she did not know in Chinese, such as mó gu (mushroom), shì jiè (the world), měi (each), dōu (all), guài wù (monster). When telling the story to the researcher, the girl used both English and Chinese to explain her ideas. Additionally, she spelled out Pinyin using English rather than Pinyin. In speaking out $M o$, for example, the initial consonant of $M$ cannot be separated with the final sound of $o$, as well as the rising tone ('). But this girl just spelled mó gu with the separate English alphabets of $\mathrm{m}, \mathrm{o}, \mathrm{g}$ and $\mathrm{u}$; shì jiè, similarly, were spelled using the English alphabets $\mathrm{s}$, h, i, j, i and e. The girl broke the rule of Pinyin and replaced Pinyin with English alphabets.

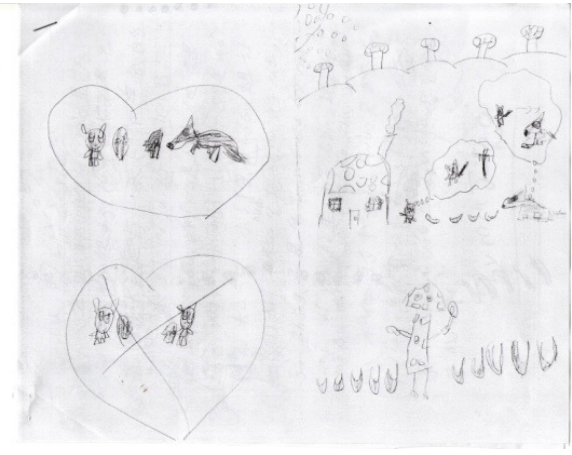

Figure 5. Illustrations.

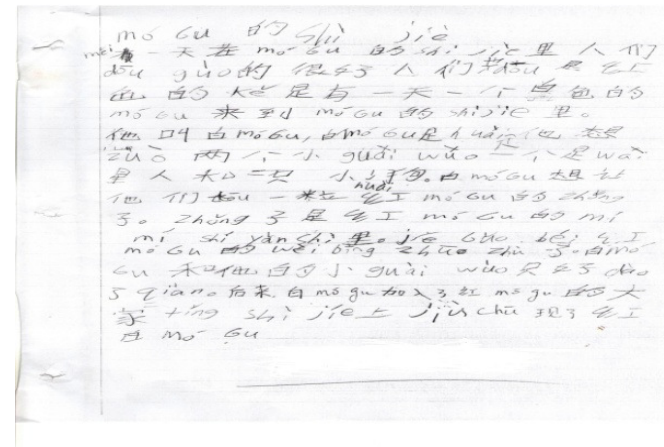

Figure 6. Draft writing.

In her writing, the student also blurred the geographical boundaries between China and Canada. For example, referring to her cousin's book report saved on her computer, which was written in Mandarin in China, the girl explained that even though she couldn't understand all 
the content of the report, she frequently opened it to see what a report or her story could look like in format. The plot of her story (for example, the fight between red and white mushrooms) was drawn partially from a popular Chinese cartoon (see Figure 7) about a battle between a family of goats and a family of wolves. She watched the cartoon when she visited her grandparents in China. Later, the girl read a book her mom brought her from China (see Figure 8), which was an updated version of the cartoon. The student's video chats with her cousins in China, and internet searches about the cartoon further contributed to her work. She might have enjoyed the process of putting beyond boundaries of what she watched, read, searched and video chatted with her cousins into her story.

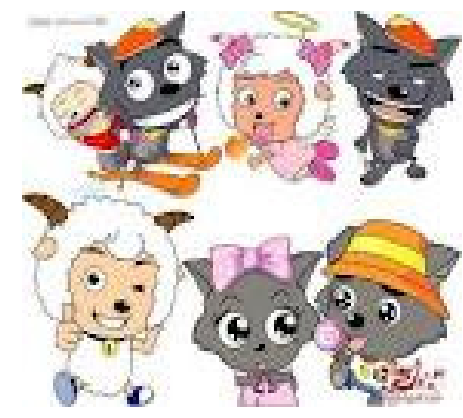

Figure 7. 喜洋洋与灰太狼[Pleasant goat and big big wolf].

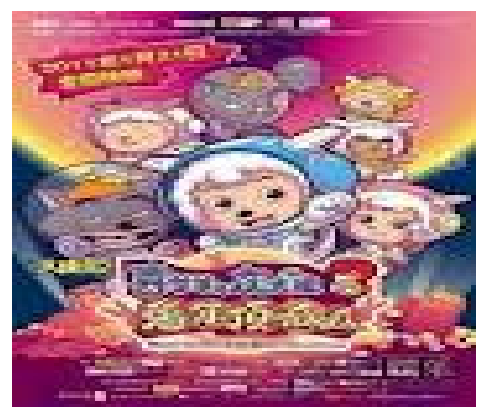

Figure 8. 喜洋洋与灰太狼之兔年顶呱呱 [Moon Castle: The space adventure, a new version of Pleasant goat and big wolf for the year of Rabbit].

The little girl's story is not only intertextual, but multimodal. Through the process of her story making, the student integrated multiple modes of communication and expression. She drew the pictures, colored the characters, handwrote the draft, typed the story and chose her favorite font, cut the printed version (see Figure 3), and pasted the pieces onto the pages with pictures that matched (see Figure 4). She combined and moved between movie, art, text, speech, physical movement, and computer to enhance her work. Many of her life experiences came together in a plurality of ongoing and unpredictable connections. She became different from her original self as she moved among the roles of student, language learner in English and Chinese, film watcher, workshop participant, book reader, story teller, illustrator, typist, book maker, and so on. 
Dufresne (2009) addresses how children in immigrant contexts conceptualize languages and self, applying several of Deleuze's concepts, including qualitative multiplicities and individuals as changeable living organisms. She sets the context of her study by describing her encounter with Mathieu in a washroom, where the boy was drawing a sobbing face with water on the mirror. Dufresne later learned the boy had been asked to sit outside because his teacher thought he talked too much in the class. However, from the boy's perspective, he was trying to help the teacher, and be a good boy. According to Dufresne, Mathieu went from feeling like a "good boy," who was adequate, to feelings of insecurity when he regarded himself as potentially being a "bad boy." His emotional progression was qualitative and heterogeneous. When his world collided with that of his teacher, opposition and difference shook up his stable territorialized assemblage, loosening and folding his world, rendering it unstable, and causing him to read himself in another way. For such a case, Dufresne suggests it is important for the educators to interrupt the virtual before it fulfills its potential and is actualized as a reality.

As the above studies show, Deleuze and Guattari's theory of rhizome and multiplicities are used to explore the dynamic and unpredictable connections in literacies and identities. The rhizome theory advances a new way of research about immigrant children, who are often marginalized by the dominant school culture. This new way of research emphasizes literacy as a process of becoming, highlighting immigrant children's multilinguality, creativity, and intersections of multiple literacies across school, home and community and across global and local contexts and the fluidity of their identities. However, "rhizome includes the best and the worst" (Deleuze \& Guattari, 1987, p. 7). It "does not distinguish the good from the evil, does not provide springboards for judging, and does not detect landmines and pitfalls" (Gregoriou, 2004, p. 241). With its endless connections to anything familiar or unfamiliar, known or unknown, rhizome can signify a sense of loss. Thus, "philosophy of education can appear not as hegemonic, 'root-like' or 'rhizomatic' but, simply, as 'confusing',' (Gregoriou, 2004, p. 238). Educators and researchers should therefore be ready for this complexity, and be prepared to think about how to transform the worlds of "what has been," "what is" and "what could be" into the world of "what should be" (Mosenthal, 2002).

\section{Pedagogical Implications of a Deleuzian Understanding of Literacies and Identities ]}

Using rhizome to represent the multiplicities of literacies and identities opens possibilities for questioning assumed sources of knowledge in the contexts of education. This encourages a shift from reliance on the static body of knowledge to openness to the dynamic process of knowing (Semetsky, 2006). This fundamental shift in perspective has far-reaching implications for education as a developing and generative practice (Semetsky, 2006).

The fundamental shift requires a reconceptualization of both teaching and learning. Rhizomes connect teachers and students to areas unforeseen; learning therefore presupposes an encounter with something unknown. Learning need not have a pre-determined body of 
knowledge as its object, and to teach also means to learn. Moreover, teaching and learning are, in Deleuzian terms, both forms of apprenticeship (Bogue, 2008). Teachers become co-apprentices with students (Waterhouse, 2011). A Deleuzian philosophy of education proposes that "the best that teachers can do is to invite their students to participate along with them in an activity rather than show them what to do or how to do it” (Bogue, 2008, p. 11).

For teachers and students to become co-apprentices requires a less hierarchical and more relational learning process which actively engages with difference (Waterhouse, 2011). To create this environment, it is important for teachers to understand and utilize immigrant children's "funds of knowledge," which specify the "historically accumulated and culturally developed bodies of knowledge and skills...essential for household or individual functioning and well-being" (Moll et al., 1992, p.133). Teachers thus recognize the importance of a family's social network in facilitating the development and exchange of knowledge, skills and labor within their social environments. In addition, students' cultural resources from peers, families and communities, including virtual communities such as the Internet, popular music, movies, television and magazines should be acknowledged as powerful funds of knowledge for children's learning in classroom. Teachers should recognize what students' everyday home brings to literacy with identities, dispositions, stories, objects, artifacts, memories, languages and resources (Gutierrez, Baquedano-Lopez \& Chiu, 1999; Moll et al., 1992). Therefore, when teachers see surprises in children's literacy practices, it is important for them to respond not by actively controlling subjects, but by facilitating their own processes of deterritorialization out of "comfort" zones (Ling, 2009; Waterhouse, 2011). This meta-reflexive response will enable them to better recognize children's creativity.

Meanwhile, it is important that teachers develop non-linear ways of thinking in order to understand the complexities of immigrant children's literacies and education. Since the textual information and narrative forms implied by conventional forms of literacy have been ruptured by various media and multiple modes of expression and communication, teachers should learn to set up nomadic classrooms wherein they challenge textual boundaries, allow children to exceed the boundaries of given territories, and encourage the unpredictable connections and creativity (Masny \& Waterhouse, 2011).

In terms of identity, there is a need to move beyond fixed and essentialized identities and "stable spatial and temporal coordinates" (Bogue, 2008, p. 3). Teachers should not equate immigrant children's identities to their cultures and ethnicities. They need to encourage immigrant children to exceed the boundaries of given territories, including racial, cultural, and linguistic territories. They need to unfold children's multiple and mobile identities (Hebert, Wilkinson \& Ali, 2008) and explore new possibilities for life.

On the whole, teachers should explore their own assumptions about literacy, language and identity and recognize that they are teaching far more than the letters of the alphabet (Masny, 2006). Rather than understanding students and interpreting the meaning of different events in 
the school according to pre-determined standards, teachers must be attentive to the conditions under which novel products and events are generated. To do this, teachers should keep asking what might happen if.... (e.g., I try a new method) (Stables, 2004). Asking such questions helps educators to examine the potential of "thinking differently" with regard to current debates around educational practices (Leach \& Boler, 1998).

\section{Conclusion}

This paper outlines the theoretical complexification of literacy and identity from the sociocultural and the poststructural perspectives. It also explores how this complexification has influenced literacy and identity research on immigrant children. A Deleuzian understanding of literacy and identity from the poststructural perspectives emphasizes the on-going and open-ended process of forming multiple identifications, as well as the mobility of experiences that transform literacies and subjects. These theoretical approaches can help us explore learning as a process of growth and change with unlimited potential through the multitude of its own transformations. Promoting the sense of heterogeneity and multiplicity that contemporary language and literacy education is embracing, a Deleuze and Guattari's rhizomatic understanding of literacy and identity is particularly helpful to understanding immigrant children who are diverse, contradictory, dynamic and changing over historical time and social space.

\section{References}

Andreotti, V. (2008). Draft model of 'stages' emerging from OSDE/TOE research [video]. Retrieved May 6, 2010 from http://www.youtube.com/watch?v=Nr6pEpeh4PI\&feature=related

Andrews, J., \& Yee, W. C. (2006). Children's 'funds of knowledge' and their real life activities: Two minority ethnic children learning in out-of-school contexts in the UK. Educational Review, 58(4), 435-449.

Baker, C., \& Luke, A. (Eds.). (1991). Towards a critical sociology of reading pedagogy. Amsterdam: John Benjamins.

Bartlett, L. (2007). To seem and to feel: Situated identities and literacy practices. Teachers College Record, 109(1), 51-69.

Bartlett, L. (2008). To seem and to feel: Engaging cultural artefacts to "do literacy". In M. Prinsloo, \& M. Baynham (Eds.), Literacies, global and local (pp. 35-50). Amsterdam: John Benjamins Publishing Company. 
Bartlett, L., \& Holland, D. (2002). Theorizing the space of literacy practices. Ways of knowing, 2(1), 10-22.

Barton, D., Hamilton, M., \& Ivanic, R. (2000). Situated literacies: Reading and writing in context. London: Routledge.

Bogue, R. (2008). Search, swim and see: Deleuze's apprenticeship in signs and pedagody. In I. Semetsky (Ed.), Nomadic education: Variations on a theme by Deleuze and Guattarie (pp. 1-16). Rotterdam: Sense Publishers.

Brandt, D., \& Clinton, K. (2002). Limits of the local: Expanding perspectives on literacy as a social practice, Journal of Literacy Research, 34(3), 337-356.

Collins, J., \& Blot, R. (2003). Literacy and literacies: Texts, power, and identity. Cambridge, England: Cambridge University Press.

Cope, B. \& Kalantzis, M. (2000). Multiliteracies: Literacy learning and the design of social futures. Melbourne, AU: Macmillan.

Cummins, J., Bismilla, V., Chow, P., Cohen, S., Giampapa, F., Leoni, L., et al. (2005). Affirming identity in multilingual classrooms. Educational Leadership, 63(1), 38-43.

Cummins, J., \& Danesi, M. (1990). Heritage languages: The development and denial of Canada's linguistic resources. Toronto: Our Schools/Our Selves Education Foundation.

Dagenais, D., Day, E., \& Toohey, K. (2006). A multilingual child's literacy practices and contrasting identities in the figured worlds of French immersion classrooms. International Journal of Bilingual Education \& Bilingualism, 9(2), 205-218.

deFina, A., Schiffrin, B., \& Bamberg, M. (2006). Introduction. In A. deFina, B. Schiffrin, \& M. Bamberg (Eds.), Discourse and identity (pp. 1-26). New York: Cambridge University Press.

Deleuze, G. (1987). Dialogues (with Claire Parnet) (H. Tomlinson \& G. Burchell, Trans.) New York: Columbia University Press.

Deleuze, G. (1990). The logic of sense (M. Lister, Trans, with C. Stivale). New York: Columbia University Press.

Deleuze, G. (1995). Negotiations 1972-1990 (M. Joughin, Trans.). New York: Columbia University Press.

Deleuze, G., \& Guattari, F. (1987). A thousand plateaus: Capitalism \& Schizophrenia part II (B. Massumi, Trans.). London: Athlone Press. 
Deleuze, G., \& Guattari, F. (1994). What is philosophy? (H. Tomlinson \& G. Burchell, Trans.). New York: Columbia University Press.

Deleuze, G., \& Guattari, F. (2004). Francis Bacon: The logic of sensation. London: Continuum.

Dufresne, T. (2009). When worlds collide: Readings of self through a lens of difference. In D. Masny, \& D. R. Cole (Eds.), Multiple Literacies Theory: A Deleuzian perspective (pp. 105-118). Rotterdam, The Netherlands: Sense Publishers.

Dufresne, T., \& Masny, D. (2005). Different and differing views on conceptualizing writing system research and education. In V.Cook and B. Basetti (Eds.), Second language writing systems. Clevedon, Multilingual Matters Ltd.

Dyson, A. H. (2001). Where are the childhoods in childhood literacy: An exploration in outer (school) space. Journal of Early Childhood Literacy, 1(1), 9-39.

Erikson, E. (1968). Identity: Youth and crisis. New York: Norton.

Ernst-Slavit, G. (1997). Different words, different worlds: Language use, power, and authorized language in a bilingual classroom. Linguistics and Education, 9(1), 25-48.

Fránquiz, M., \& De La Luz Reyes, M. (1998). Creating inclusive learning communities through English language arts: From Chanclas to Canicas. Language Arts, 75(3), 211-220.

Freire, P. (1972). The pedagogy of the oppressed. London: Sheed and Ward.

Gee, J. P. (1996). Social linguistics and literacies: Ideology in discourses. London: Taylor \& Francis.

Gee, J. P. (2008). Social linguistics and literacies: Ideology in discourses (3rd ed.). New York: Routledge.

Gregoriou, Z. (2004). Commencing the Rhizome: Towards a minor philosophy of education. Educational Philosophy and Theory, 36(3), 233-251.

Gutierrez, K. D., Baquedano-Lopez, P., Alvarez, H. H., \& Chiu, M. M. (1999). Building a culture of collaboration through hybrid language practices. Theory into Practice,38(2), 87-93.

Hagood, M. C. (2009). Mapping a rhizome of $21^{\text {st }}$ century language arts: Travel plans for research and practice. Language Arts, 87(1), 39-48. 
Hébert, Y. (2001). Identity, diversity, and education: A critical review of the literature. Canadian Ethnic Studies, 33(3), 155-177.

Hébert, Y., Wilkinson, L., \& Ali, M. (2008). Second generation youth in Canada, their motilities and identification: Relevance to citizenship education. Brock Journal of Education, 17(1), 50-70.

Kamberelis, G. (2004). The rhizome and the pack: Liminal literacy formations with political teeth. In K. Leander \& M. Sheehy (Eds.), Spatializing literacy research and practice (pp. 161-198). New York: Peter Lang.

Kendrick, M., Rogers, T., Smythe, S., \& Anderson, J. (2005). Portraits of literacy across families, communities, and schools: An introduction. In J. Anderson, M. Kendrick, T. Rogers \& S. Smythe (Eds.), Portraits of literacy across families, communities, and schools: Intersections and tensions (pp. 1-17). Mahwah: Lawrence Erlbaum Associates, Inc.

Kramsch, C. (2009). The Multilingual subject. New York: Oxford University Press.

Leach, M., \& Boler, M. (1998). Gilles Deleuze: Practicing education through flight and gossip. In M. Peters (Ed.), Naming the multiple: Poststructuralism and education (pp. 149-172). Westport: Bergin \& Garvey.

Leander, K., \& Rowe, D. (2006). Mapping literacy spaces in motion: A rhizomatic analysis of a classroom literacy performance. Reading Research Quarterly, 41(4), 428-460.

Lemke, J. (2008). Identity, development and desire: Critical questions. In C. R. Caldas-Couthard \& R. Iedema (Eds.), Identity trouble: Critical discourse and contested identities (pp. 17-42). London: Palgrave McMillan.

Lewis, C., Enciso, P., \& Moje, E. B. (Eds.). (2007). Reframing socio-cultural research on literacy: Identity, agency, and power. Mahwah: Erlbaum.

Lewis, C., \& Del Valle, A. (2009). Literacy and identity: Implications for research and practice. In L. Christenbury, R. Bomer, \& P. Smagorinsky (Eds.), Handbook of adolescent literacy research (pp.307-322). New York: Guilford.

Li, G. (2001). Literacy as situated practice. Canadian Journal of Education, 26(1), 57 -75.

Li, G. (2006). What do parents think? Middle-class Chinese multilingual parents' perspectives on literacy learning, homework, and school-home communication. The School and Community Journal, 16(2), 27-46. 
Ling, S. (2009). Thinking like grass, with Deleuze in education? Journal of the Canadian Association for Curriculum, 7(2), 31-48.

Luke, A. 2004. On the material consequences of literacy. Language and Education, 18(4), 331-335.

Maguire, M. H. (2005). Identity and agency in primary trilingual children's multiple cultural worlds: Third space and heritage languages. In J. Cohen, K. T. McAlister, K. Rolstad, \& J. MacSwan (Eds.), Proceedings of the $4^{\text {th }}$ International Symposium on Bilingualism (pp. 1423-1445). Somerville: Cascadilla Press.

Manyak, P. C. (2001). Participation, hybridity, and carnival: A situated analysis of a dynamic literacy practice in a primary-grade English immersion class. Journal of Literacy Research, 33(3), 423-465.

Manyak, P. C. (2004). "What did she say?" Translation in a primary-grade English immersion class. Multicultural Perspectives, 6(1), 12-18.

Martin-Jones, M., \& Jones, K. (Eds.). (2000). Multilingual literacies: Reading and writing different worlds. Amsterdam, The Netherlands: John Benjamins Publishing.

Masny, D. (2005). Multiple literacies: An alternative OR beyond Friere. In J. Anderson, M. Kendrick, T. Rogers \& S. Smythe (Eds.), Portraits of literacy across families, communities, and schools: Intersections and tensions (pp. 71-84). Mahwah: Lawrence Erlbaum Associates.

Masny, D. (2006). Learning and creative processes: A poststructural perspective on language and multiple literacies. International Journal of Learning, 12(5), 147-155.

Masny, D. (2008). A Multiple Literacies Theory: What it produces. In C. Maltais (Ed.), Perspectives on multiple literacies: International conversations (pp. 13-17). Calgary: Detselig Enterprises Ltd.

Masny, D. (2009a). Introduction to Multiple Literacies Theory: A Deleuzian perspective. In D. Masny, \& D. R. Cole (Eds.), Multiple Literacies Theories: A Deleuzian perspective (pp. 1-11). Rotterdam, The Netherlands: Sense Publishers.

Masny, D. (2009b). Literacies as becoming: A child's conceptualizations of writing systems. In D. Masny, \& D. R. Cole (Eds.), Multiple Literacies Theory: A Deleuzian perspective (pp. 13-30). Rotterdam, The Netherlands: Sense Publishers.

Masny, D. (2010). Multiple Literacies Theory: How it functions, what it produces. Perspectiva, 28(2), 337-352. 
Masny, D., \& Cole, D. R. (2007). Applying multiple literacies in Australian and Canadian contexts. In A. Simpson (Ed.), Future directions in literacy: International conversations conference proceedings (pp. 190-211). Sydney, Australia: Sydney University Press. Retrieved March 21, 2010, from http://ses.library.usyd.edu.au/bitstream/2123/2336/1/FutureDirections_Ch11.pdf

Masny, D., \& Cole, D. R. (2009). Introduction to Multiple Literacies Theory: A Deleuzian perspective. In D. Masny, \& D. R. Cole (Eds.), Multiple Literacies Theory: A Deleuzian perspective (pp. 1-11). Rotterdam, The Netherlands: Sense Publishers.

Masny, D., \& Waterhouse, M. (2011). Mapping territories and creating nomadic pathways with Multiple Literacies Theory. Journal of Curriculum Theorizing, 27(3), 287-307.

McCarthey, S. J., \& Moje, E. B. (2002). Identity matters. Reading Research Quarterly, 37(2), $228-238$.

Michael-Luna, S. (2008). Todos somos Blancos/We are all white: Constructing racial identities through texts. Journal of Language, Identity \& Education, 7(3), 272-293.

Moje, E., Ciechanowski, K., Kramer, K., Ellis, L., Carrillo, R., \& Collazo, T. (2004). Working toward third space in content area literacy: An examination of everyday funds of knowledge and discourse. Reading Research Quarterly, 39(1), 38-70.

Moje, E. B., \& Luke, A. (2009). Literacy and identity: Examining the metaphors in history and contemporary research. Reading Research Quarterly, 44(4), 415-437.

Moll, L. C., Amanti, C., Neff, D., \& Gonzalez, N. (1992). Funds of knowledge for teaching: Using a qualitative approach to connect homes and classrooms. Theory into Practice, 31(2), 132-141.

Mosenthal, P. (2002). Introduction to NRC's white papers. Journal of Literacy Research, 34(2), xv-xvii.

New London Group. (1996). A pedagogy of multiliteracies: Designing social futures. Harvard Educational Review, 66(1), 60-92.

Olsson, L. M. (2009). Movement and experimentation in young children's learning: Deleuze and Guattari in early childhood education. London: Routledge.

Pahl, K. (2002) "Ephemera, mess and miscellaneous piles: Texts and practices in families." Journal of Early Childhood Literacy, 2(2), 145-166. 
Pahl, K., \& Rowsell, J. (2005). Literacy and education: Understanding the New Literacy Studies in the classroom. London: Paul Chapman Publishing.

Parke, T., Drury, R., Kenner, C., \& Robertson, L. H. (2002). Revealing invisible worlds: Connecting the mainstream with bilingual children's home and community learning. Journal of Early Childhood Literacy, 2(2), 195-220.

Pérez, B. (2004). Becoming biliterate: A study of two-way bilingual immersion education. Mahwah: Lawrence Erlbaum Associates, Inc.

Perry, N. J., Kay, S. M., \& Brown, A. (2008). Continuity and change in home literacy practices of Hispanic families with preschool children. Early Child Development \& Care, 178(1), 99-113.

Prinsloo, M., \& Baynham, M. (2008). Introduction: Renewing literacy studies. In M. Prinsloo, \& M. Baynham (Eds.), Literacies, global and local (pp. 1-13). Amsterdam: John Benjamins Publishing Company.

Rampton, B. (1998). Speech community. In J. Verschueren, J. Ostman, J. Blommaert \& C. Bulcaen (Eds.), Handbook of pragmatics (pp. 1-34). Amsterdam: John Benjamins.

Semetsky, I. (2006). Deleuze, education and becoming. Rotterdam: Sense Publishers.

Semetsky (Ed.). (2008). Nomadic education: Variations on a theme by Deleuze and Guattarie. Rotterdam: Sense Publishers.

Soltero-González, L. (2008). The hybrid literacy practices of young multilingual children: Lessons learned from an English-only preschool classroom. Bilingual Research Journal, 31(1\&2), 75-93.

Stables, A. (2004). Responsibility beyond rationality: The case for rhizomatic consequentialism. International Journal of Children's Spirituality, 9(2), 219-225.

Street, B. V. (1984). Literacy in theory and practice. Cambridge: Cambridge University Press.

Street, B. V. (1995). Social literacies: Critical approaches to literacy in development, ethnography and education. New York: Longman Publishing.

Street, B. V. (2003). What's "new" in New Literacy Studies? Critical approaches to literacy in theory and practice. Current Issues in Comparative Education, 5(2), 77-91.

Taylor, L. K., Bernhard, J. K., Garg, S., \& Cummins, J. (2008). Affirming plural belonging: Building on students' family-based cultural and linguistic capital through multiliteracies pedagogy. Journal of Early Childhood Literacy, 8(3), 269-294. 
Volk, D., \& Angelova, M. (2007). Language ideology and the mediation of language choice in peer interactions in a dual-language first grade. Journal of Language, Identity \& Education, 6(3), 177-199.

Wallace, C. (2005). Conversations around the literacy hour in a multilingual London primary school. Language \& Education: An International Journal, 19(4), 322-338.

Waterhouse, M. (2011, May). Rhizocurriculum: Instances of a Nomad-Education. Paper presented at CSSE 2011, Fredericton, New Brunswick.

Weedon, C. (1987). Feminist practice and poststructuralist theory. Oxford, England: Basil Blackwell.

Zhang, Y. (2011, March). Literacy, identity and language education research: From sociocultural to poststructuralist perspectives. Paper presented at the 2011 Annual Conference of the American Association for Applied Linguistics (AAAL), Chicago, Illinois. 